\title{
Oppression of General IDI Amin Dada in Ruling People (Objective)
}

\author{
Suswanto Ismadi Megah \\ English Education Department \\ University of Riau Kepulauan \\ megah76@yahoo.co.id
}

\begin{abstract}
This study analyzed the ruling of the Idi Amin Dada. This used to identify how he oppressed his people cruelly. This study applied Marxist theory by Karl Marx and social class by Lewis. In addition, this study also explained how the new independent country ruled by the military system. Marxist Theory and social class theory analyzed the class onflict between the strong and the weak people. Status in social analysis and in practice, the notion of social class The dictatorships of his government made thousands people killed. This study applied qualitative research method. The data obtained from the scene and script of the rise and Fall Idi Amin Movie. The result of the study that the oppression occurred during his ruling country. The oppressions were he oppressed his people by his power. His soldiers who oppressed civil cruelly. Then the oppression occurred between man and women, this reflected General Idi Amin and his wives. The last was he oppressed the foreigners to get out of Uganda.
\end{abstract}

Keywords : oppression, ruling and idi Amin

\section{INTRODUCTION}

Literatures are as a means of communication between literary works and society. Literature always contains thoughts, ideas, narratives, and the message to be communicated to the public. Literature is dealing with human beings in society and the human effort to adapt and attempt to change society. Hence, a literary work is a reflection of human's experience in their life. The experience can be good or bad. Therefore, the experience will influence the human behavior to face their problem. Endraswara (2011:20), literature is presented of feeling, thingking, and willing of man as a society and politly of human. So the right in a literary is depand of how the people expression of it.

Therefore, a literary work is reflection of the event of life in society. In here the writer takes literature as topic of her thesis because as we know through literature we can improve our life, enrich our experience life and give us wiser ways to face problems in our lives. In other words, literature is useful for our life because it can give us a lot of lessons in the 
literature works. Literature consists of many forms: poetry, plays, short stories, drama and novel and so on. Moreover, literature can be the body of written or spoken works of language even more visual work such as movie or picture so; literary work can be advanced in period, culture, art of a literary. Then the body of written work is produced by literary man or scholars in advancing of this literary field. Written materials such as poetry, novels, essays, etcetera. Hence, the body of written work produced by scholars or researchers in given field. Written materials such as poetry, novels, essays, etcetera. So, literature is one of the vital records of what human have seen in social life. What they thought and felt about the aspect of it or what they have experience of on life or all humans activities related to society, religion, education, politic, philosophy, social, etc. Movie recently is easily known because the technology has grown fast, so, movie or film is as media to express human being's ideas. The idea can be literary work such as novel or film. Movie of The Rise and Fall of Idi Amin, told about the Uganda President who is also known as Amin: in The Rise and Fall of Amin, It was produced in 1981. It was a biographical film directed by Sharad Patel and starring Joseph Olita as Idi Amin.

Therefore, this study had items to be analyzed those could be identified that there are some will be used as questions and those will be used in the formulation of the study. The conflict between two different classes, namely the upper class and lower class. The strong man and his men oppresses the opposition who stay across him.

\section{Underlying Theory}

Theory about society is about socialism. Thus, socialism is ideology to value about social norm. So it can stated as social value. 'Social value' refers to wider non-financial impacts of programs, organizations and interventions, including the wellbeing of individuals and communities, social capital and the environment. These are typically described as 'soft' outcomes, mainly because they are difficult to quantify and measure. Sociology is the study of literature that focuses on the problems of mankind. This is due to the literature often reveals the struggle of human beings to determine their future, imagination, feelings and intuition. From this argument, it appears that the long struggle of human life will always color the literary text. In addition, Marxist theory also explains about social conflict. Scheweickart (2002:25-28) Marxist is of the kinds of criticism represented in this guide, Marxist criticism has the longest history. Karl Marx himself made important general statement about culture and society in the 1850s. Even so, it is correct to think of Marxist critics' as a twentieth- century phenomenon. 
The Marxist approach to literature is based on the philosophy of Karl Marx, a German philosopher and economist. His major argument was that whoever controlled the means of production (the factories) in a society controlled the society. Marx noted a disparity in the economic and political power enjoyed by the factory owners and that allowed to the factory laborers. He believed that the means of production (i.e., the basis of power in society) should be placed in the hands those who actually operated them. He wrote that economic and political revolutions around the world would eventually place power in the hands of the masses, the laborers. To read a work from a Marxist perspective, one must understand that Marxism asserts that literature is a reflection of culture, and that culture can be influenced by literature. Marxists believe literature can instigate revolution.

Class conflict firstly occurred in the nineteenth century in England or France would experience the effect of the industrial revolution. At the era, the owner of the production would exploit the labor to fulfill the product's targets, whereas another side small industries were swept by the giant industries, mastered by the capitalists or bourgeois. The composition reflected class competition between the owner and the bourgeois versus the labor or the proletariat. Marx criticized that the owner as the oppressor while the labor as the oppressed, so the oppressor made oppression whatever the oppressor wants to the labor. Therefore, it caused Marx dreamed classless society without any differences. It was as sheer utopia that it was difficult to embody it. Nevertheless, Marx empowered his thought and his ideas to influence the labor movement, and to master the production factor under the labor power. His desire has created the dictatorship of the proletariat, because the proletariat held the production.

Teeuw (1984:237) that literary work creates sense of life and interpret as they do in life that we live in ourselves. The historical change that had been shown in Idi's Movie was a picture of the real life in the power strength had made great gap between the owners of the capital and the labours. The owners forced the lebours to work hard while most the benefit was for the owner. This condition had created more poor people while the have was only a few group of the people. According to Lewiss (1993) that social class can be defined as Social class (or, simply, class), as in class society, is a set of concepts in the social sciences and political theory centered on models of social stratification in which people are grouped into a set of hierarchical social categories. Then Andrew (2001) adds that the most common being the upper, middle, and lower classes. Furthermore, Robert (2003:189) states that Class is an essential object of analysis for sociologists, political scientists, anthropologists, and social historians. However, there is not a consensus on the best definition of the "class," 
and the term has different contextual meanings. In common parlance, the term "social class" is usually synonymous with "socio-economic class," defined as "people having the same social, economic, or educational status," e.g., "the working class"; "an emerging professional class." However, academics distinguish social class and socioeconomic status, with the former referring to one's relatively stable sociocultural background and the latter referring to one's current social and economic situation and, consequently, being more changeable over time. Joyce (1999:21) states that the capitalist was usually a call for modern capitalist. This was caused that the capitalist was very important element in industry as they owned the capital. Joyce (1999:21) states that the capitalist was usually a call for modern capitalist. This was caused that the capitalist was very important element in industry as they owned the capital. While Magnis (1999:113) classifies the capitalist society into three levels, those are wagelabour, capital owners, and landowner. Those classes can be divided into distinctively-different classes. Those levels can be divided into two classes, namely the working class or upper class and the owning class or lower class. Those can also be called as the oppressor for the upper class, while the oppressed for the lower.

\section{METHODOLOGY}

This study used qualitative research type. Qualitative design refers to a research procedure which produces descriptive data. state that human being's written or spoken words and their observable behaviors were the examples of the descriptive data. a descriptive research was a method that deals with the possibilities to solve an actual problem by collecting, classifying, analyzing, and interpreting data. In addition, a descriptive-qualitative method was similar with qualitative research because it described particular phenomena or situations that become the focus of the research. The writer would also use Marxism literary approach, which shared an issue about social class about economic power that led to political power, social gap and clash between different classes. Therefore, the writer applied qualitative research in this study of The Rise and Fall Idi Amin by using Marxist theory in analyzing of the data. The data source obtained from Rise And Fall Idi Amin Movie Internet downloaded. Then the data analyzed qualitatively.

\section{RESULTS}

The data finding consists of conflict between the oppressor and the oppressed. The data found the oppressors consists of the powerful people such as the general Idi Amin. He 
oppressed his people. The soldiers who oppressed civil. The conflict between man and women, this reflected General Idi Amin and his wives. Then conflict between the older and the Youngers. This reflected y general Amin and his son. The last is the conflict between the local and the foreigners. This conflict reflected between local Ugandans with Indian Ugandan. The last conflict local government with foreign journalist.

Marxism that will be analyzed is not in industrial environment but in Political field as ruler and dictator, and he has name black Hitler or Black rose, the term of bourgeoisie is replaced with aristocrat. The data analyzed divided into three main subjects of analysis. They are the exposition of the Uganda Revolution, the triggers and the effects of the Uganda Revolution, and the ideology of the author that is reflected in the Movie. The writer used base and superstructure theory to analyze the triggers of the Uganda revolution in the Movie while dialectical materialism is used in the analysis of the effect of the Uganda revolution in the Movie.

\section{a. Conflict between government and the civil people}

The powerful general Idi Amin in controlling his men (soldiers). He ordered his men to occupy all government department, including hospital. His men attack hospital although the operation is going on. He replaced former president with military coup. He uses military law. He oppresses civil. This can be seen in the picture of the data 1 when the doctor is doing surgery in the operation room, the soldier shot the gun. Nobody can stop it. This shows that government as the upper class can control the people as the lower class.

\section{b. Conflict between Military and the civil people}

When general Idi Amin in joining a fiesta or party. He saw a beautiful young girl who was dancing with her boy friend. Then general Idi Amin order his men (intelligence) to caught her boy friend the conflict between the oppressor general Idi Amin and his people. This occurred when he joined in a party. He saw beautiful young girl, then he is interested her. Therefore, he ordered his men to vanished her boy friend. This show the upper class as like general idi Amin easily to get everything. This is also seen in following data below.

\section{c. Conflict between Man and Woman}

The general Idi Amin has many wives, one of them killed because she was accused that she has another man in her heart, then he killed his wife. When general Idi Amin and his wife in the bathroom. His wife is ordered to clean his body although he is in serious 
thing but he still oppressed his wife to serve him. This as like in the dialogue below. "She is being sick my Excellency,... It is not your business!!"

\section{d. Conflict between Local and Foreigner}

In following data is shown that in the Marxist theory that the upper class always oppress the lower class as the weak class. This shown buy the Uganda who has ancestor from India, they are tend to be oppressed class. They are thrown out from Uganda.

\section{DISCUSSION}

This study concluded that Idi Amin Movie used his power to oppress his people. The oppression were the soldiers who oppressed civil. The conflict between man and women, this reflected General Idi Amin and his wives. The last is the conflict between the local and the foreigners. This conflict reflected between local Ugandans with Indian Ugandan. The last conflict local government with foreign journalist.

\section{REFERENCES}

Andrew, Barry.(2001). Political machines. London: The Athlon Paper Press

Endraswara, Suwardi. (2011). Metodologi penelitian sastra epistemologi, Model, teori, dan aplikasi.Yogyakarta: Caps

Joyce, Mc. Chael. (1999). Class.New York: Oxford University Press.

Magnis, Frans. (1999). Sosiolalisme utopis ke perselisihan revosionism. Jakarta: PT. Gramedia.

Lewiss, M.(1993). Social antropology and perspective. London: Penguin

Robert, Penney. (2003). "Class, social". In Christensen, Karen \& Levinson, David. Encyclopedia of community: from the village to the virtual world, Volume 1. SAGE.

Scheweickart, David. (2002). Marxism and transition to communist. "Modernization, globalization and China's path in economic development. Hangzhou, China. July 5-7, 2

Teeuw, A. (1984). Sastra dan ilmu sastra: Pengantar teori sastra. Jakarta: Pustaka Jaya 